\title{
On-Line Measurement of Wood Surface Smoothness
}

\section{Online mjerenje glatkoće površine drva}

\author{
Original scientific paper • Izvorni znanstveni rad \\ Received-prispjelo: 20. 10. 2019. \\ Accepted-prihvaćeno: 28. 4. 2020. \\ UDK: $630 * 823.121$ \\ https://doi.org/10.5552/drvind.2020.1970
}
(C) 2020 by the author(s).
Licensee Faculty of Forestry, University of Zagreb. This article is an open access article distributed under the terms and conditions of the
Creative Commons Attribution (CC BY 4.0) license.

\begin{abstract}
The latest progress in the field of optics and microelectronics resulted in the development of new generation vision systems capable of scanning surface topography with very high sampling frequencies. The blue color of illuminating light as well as novel systems for controlling ultra-thin laser line thickness allows the measurement of the porous surface of wood with a triangulation method. Three alternative sensors were tested here in order to verify their suitability for the determination of surface topography in the industrial environment. The scanning head was installed at the exit zone of the four-side profiling moulder and was set to scrutinize the wood surface shape line-by-line, immediately after profiling. The sensor was also tested for automatic detection of surface defects appearing on the elements after sanding, wetting and painting with various finishing products. The set of pilot test results is presented, together with an original algorithm for real-time surface defects detection.
\end{abstract}

Keywords: wood surface smoothness; triangulation scanner; surface defects; in-line

SAŽETAK • Najnoviji napredak u području optike i mikroelektronike rezultirao je novom generacijom skenera koji mogu skenirati topografiju površine vrlo visokom frekvencijom uzorkovanja. Svjetlost plave boje, kao i novi sustav za kontrolu vrlo tanke laserske zrake omogućuju mjerenje porozne površine drva metodom triangulacije. Testirana su tri alternativna senzora kako bi se potvrdila njihova prikladnost za određivanje topografije površine u industrijskim uvjetima. Glava za skeniranje postavljena je na izlazu četverostranoga profilnoga glodala kako bi se odmah nakon profiliranja pomno linijski skenirala površina drva. Senzor je također testiran za automatsko otkrivanje površinskih grešaka na elementima nakon brušenja, vlaženja i premazivanja različitim premaznim materijalima. Predstavljen je set rezultata pilot-ispitivanja, zajedno s originalnim algoritmom za otkrivanje površinskih grešaka u realnom vremenu.

Ključne riječi: glatkoća površine drva; triangularni skener; površinske greške; linijsko skeniranje

\section{INTRODUCTION \\ 1. UVOD}

Surface smoothness of products manufactured from wood is a critical property highly affecting product quality, its value and in-service life performance (Sandak, 2005). In a majority of cases, the surface of wood is an effect of the material allowance removed with a sharp cutting edge. The magnitude of roughness depends on several factors, where material properties, machining process kinematics, cutting tool conditions and machining imperfections are dominant (Škaljić et al., 2009; Sofuoğlu, 2015). The ability for monitoring surface quality at the early stage of the production process was always a desire of process engineers (Nasir and Cool, 2018). Several methods were proposed for that purpose, but none of these were widely accepted by the wood industries. The superior methodology for

\footnotetext{
${ }^{1}$ Authors are researchers at InnoRenew CoE, Isola, Slovenia.

${ }^{2}$ Author is researcher at University of Primorska, Andrej Marušič Institute, Koper, Slovenia.

${ }^{3}$ Authors are researchers at Gdansk University of Technology, Faculty of Mechanical Engineering, Department of Manufacturing Engineering and Automation, Gdansk, Poland.

${ }^{4}$ Author is researcher at University of Primorska, Faculty of Mathematics, Natural Sciences and Information Technologies, Koper, Slovenia.

${ }^{5}$ Author is researcher at SylvaDrewno Sp z o.o., Wiele, Poland.
} 
monitoring surface smoothness should be non-contact, very fast, allowing on-line (preferably in-process) assessment and accurate enough to detect undesired defects (Zhao, 1992; Zhao, 1995; Župerl and Čuš, 2019; Dobrzynski et al., 2019; Lu et al., 2019). The best surface roughness scanner should allow measurement not only of a surface profile but rather the whole surface area (Kiliç et al., 2018; Lu et al., 2017).

Wood surface measurements can be performed in industrial conditions assuming in-line, on-line or offline strategies (Figure 1). In-line installation of the smoothness sensor allows early detection of machining imperfections as the sensor monitors roughness directly after the cutting tool. In that case, the scanning frequency must be high enough to assure sufficient representation of the surface, considering very high feed speeds of modern processing systems. The sensor itself has to be very rigid and resistant to harsh environments (dust, vibrations, shocks, etc.). As an alternative to the in-line approach, surface smoothness can be measured on the selected representative samples following an off-line strategy. In that case, the sample is removed from the production line and presented to the measurement system in a specially conditioned place (e.g., laboratory). Off-line measurement allows superior reproduction of surface topography, including whole area evaluation as well as high topography magnification and optimal resolution. An apparent limitation of this solution is manual operation and inability for continuous analysis of a very limited number of samples. In between in-line and off-line is, therefore, on-line strategy, where the roughness sensor is installed separately from the woodworking machines on the main conveyer or for-the-purpose separated by-stream measurement line. On-line installation of the sensor allows measurement of all (or at least a high fraction) of produced surfaces, substantially increasing reliability of the quality assurance system (Lu and Tian, 2006).

The latest advancement in the field of optics and microelectronics resulted in the development of new generation vision systems capable of scanning surface topography. Interferometry, confocal microscopy or image stacking decomposition, are today widely used methods for surface topography mapping in laboratories or off-line applications (de Grot, 2019). On the other hand, triangulation systems allow for scanning surfaces with very high sampling frequencies, while still assuring accurate surface roughness reconstruction (Sandak and Negri, 2007). Problematic red-light scatter on the fibrous surface of wood has been recently minimized by implementing blue lasers as a source of light (ك̌ustek and Siklienka, 2018). In that case, short light wavelengths minimize laser line thickness, di- minishing the unwanted "tracheid effect". Such triangulation systems have been recently introduced on the market but never tested for their suitability in wood industries.

Aesthetical function of the wood surface dominates the highly customer-oriented market, where several alternatives to wood are available in a variety of applications (Manuel et al., 2015). One of the most demanding sectors is window production, where technical requirements for the surface quality of the final product are extremely high. Wood machining is an integral part of the production process for wooden window frames, where the surface generated by planing directly affects the sequence of operations that follow, especially surface finishing by coating or painting. In practice, it is very difficult to determine the state of cutting tools, where these are required to be re-sharpened or replaced. The excessive presence of surface defects increases production costs and absorbs qualified human resources for reparations. The challenge for this project was, therefore, to investigate the possibility of integrating state-of-the-art optical sensors with running production lines. Such sensors should scan the generated surface topography in-line or on-line, assuring autonomous operation and continuous data acquisition. Use of the sensor-derived data was to both:

- alert operators about the presence of surface defects resulting from the wood cutting process, and

- determine optimal time for replacement of the cutting tools, assuring compromise between long service life of the tool itself and superior surface quality of products.

This paper presents some of the preliminary results obtained during a pilot industrial test, together with a prototype software solution developed for the analysis of data provided by the surface smoothness sensor.

\section{MATERIALS AND METHODS} 2. MATERIJALI I METODE

\subsection{Triangulation sensors \\ 2.1. Senzori za trianguliranje}

Three alternative sensors were identified for testing in order to verify their suitability for the determination of wood surface topography in the industrial environment:

- Keyence LJ-7200 (scanned profile length: $62 \mathrm{~mm}$, spatial resolution: $0.10 \mathrm{~mm})$

- Keyence LJ-7080 (scanned profile length: $32 \mathrm{~mm}$, spatial resolution: $0.05 \mathrm{~mm})$

- Keyence LJ-7020 (scanned profile length: $7 \mathrm{~mm}$, spatial resolution: $0.01 \mathrm{~mm}$ ) in-line

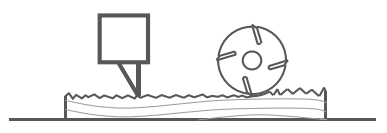

on-line

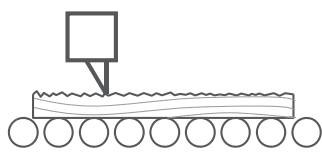

off-line

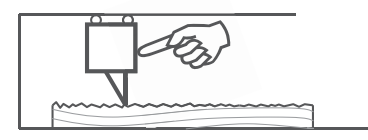

Figure 1 Assessment strategies for wood surface smoothness in the production factory

Slika 1. Strategije procjene glatkoće površine drva u proizvodnji 


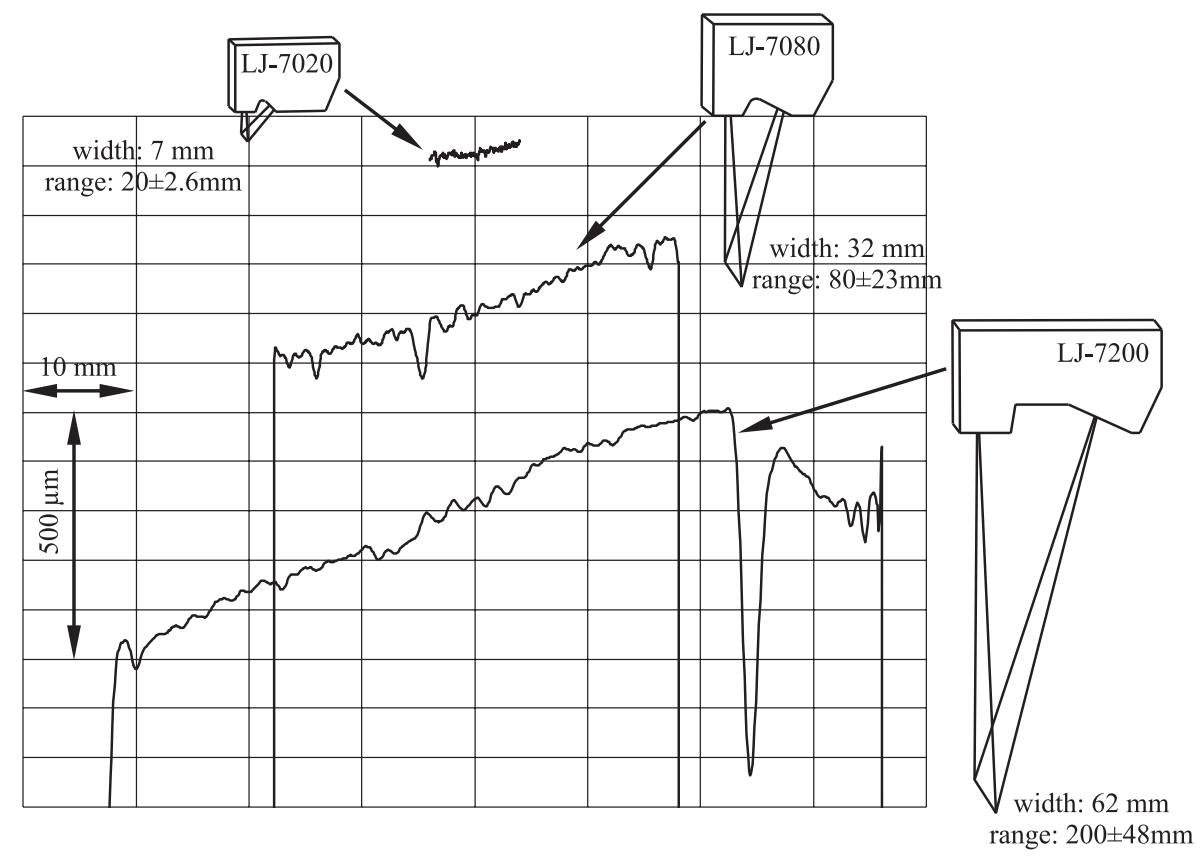

Figure 2 Examples of planed wood (Scots pine) surface profiles acquired with tested sensors: Keyence LJ-7020, LJ-7080 and LJ-7200

Slika 2. Primjer profila površine izblanjanog drva običnog bora dobivenih ispitnim senzorima Keyence LJ-7020, LJ-7080 i LJ-7200

All sensors were equipped with similar CCD detectors but different arrangement of optical components (Keyence, 2019). As a result, with increasing scanning length, the spatial resolution (along the scanned profile) was reduced, as well as accuracy for the determination of the minute surface irregularities, such as wood anatomical components. Figure 2 presents an example of surface profiles acquired by three sensors from the same wood sample (planed friezes made of Scots pine, measured in slightly different positions along the piece). It is evident that LJ-7200 covered a very wide part of the object, but the surface definition was relatively poor, especially when compared with LJ-7020. This disqualified the wide-range sensor for further investigations of surface smoothness assessment; however, this sensor has been identified as an optimal quality control tool for the accuracy of profiling complex frame shapes used in window production. Both LJ-7080 and LJ-7020 sensors were selected for further tests and integrated with production lines.

The scanning frequency of triangulation scanners varied between $200 \mathrm{~Hz}$ and $2000 \mathrm{~Hz}$, depending on the expected scanning density and available data for postprocessing. It was possible to increase the scanning frequency even more (top scanning speed of $16 \mu \mathrm{s} / 62.5$ $\mathrm{kHz}$ ), but, in that case, spatial resolution of the surface maps along the scanned profile decreased due to necessary pixel binning.

Two optional placements for the smoothness sensor were recognized in the production line of the window producing factory:

- in-line: installed directly after the final planing head of the profiling moulder and before the water wetting station, and

- on-line: on the conveyer transporting elements between operations.
Both options were tested during the pilot, providing important decision-making observations and a series of topography maps acquired during scanning of the produced elements. The in-line option was superior from the reliability point of view, assuring very fast and direct detection of surface defects - linking the surface quality with a specific cutting tool. An important disadvantage was limited access to the sensor due to restricted space available in the machine and its vibrations. It is expected that the optical sensor has to be frequently inspected and cleaned from dust present in the vicinity of the cutting tools. The second obstacle for in-line implementation was the fact that, according to the technological process, the wood surface of window frame elements was wetted in order to lift any loose fibers before implementing other operations. The wetting process resulted in dramatic changes of the wood surface smoothness itself (Molnár et al., 2019).

The on-line option was identified as superior for the pilot testing as it allowed the measurement of real production samples as well as pre-selected specimens containing specific surface characteristics. In this case, the belt conveyor was adapted as a sample feeder, while the smoothness sensor was fixed to the conveyor mechanical frame. The feed speed was set at $5 \mathrm{~m} / \mathrm{min}$, which corresponded to the real production speeds used in the window frame factory.

In both cases (in-line and on-line), the data from sensors were properly acquired and stored on the computer hard disk for further post-processing.

\subsection{Model samples \\ 2.2. Model uzoraka}

The engineers supervising the production process in the window factory pre-selected a number of samples representing diverse surface quality grades corresponding to different production stages and examples 
of surface defects commonly occurring on the produced wooden elements. The samples included: raw resources arriving from the suppliers - before profiling, wooden elements resulting from planing with different configurations of the grain angles, elements after surface sanding, elements with repaired defects by means of filling and finished wooden frames, assuming different coatings, colors and number of layers. The identification, as well as description of surface defects, was conducted in collaboration with process engineers and operators. The most problematic surface defect highlighted was torn grain.

\subsection{Software for data post-processing}

\subsection{Softver za obradu podataka}

The quantity of data generated during wood surface scanning with investigated sensors was very high, requiring development of dedicated software tools enabling real-time data acquisition and data mining. Custom software was developed in LabView 2017 (National Instruments) implementing the algorithm presented in Figure 3. The data were acquired as a stream directly from the triangulation sensor controller. These were post-processed twofold:

- grey scale image was generated to simplify visualization of the surface topography, and

- data were processed independently for each scanned profile, determining standardized surface roughness parameters and variation along the sample length.

The surface images (maps) were used for further detailed analysis by means of open-source software Gwyddion (2019), which allowed optional filtering, flattening as well as computation of 3D surface roughness parameters, among others. The flattening of surface topography maps was performed by subtracting the main plane from the primary dataset. No band pass filtering was applied here to extract topography components, with exception of spike removal. Spikes were unwanted artefacts in the primary profiles that were not related to the measured surface but to the triangulation system errors, such as reflectance and shape discontinuity, corner or sensor occlusion (Sandak, 2007). These were removed by implementing "mask of outliers" tool of the Gwyddion software.

From the industrial implementation point of view, however, the second approach (single profile at once analysis) was more efficient. The raw set of data collected from the sensor was first filtered to remove border artefacts and spikes (single pixel wide and exceptionally high data points far from the mean line). The form error was also removed by extracting linear fitting of the surface profile points $\left(r_{i}\right)$. Root Mean Square deviation of the primary profile $(P q)$ parameter was then computed on the filtered and flattened data according to ASME B46.1-2009 and ISO 4287-1997, as presented in Eq. 1:

$$
P q=\sqrt{\frac{1}{n} \sum_{j=1}^{n} r_{j}^{2}}
$$

The $P q$ value can then be confronted with the threshold, and the operator can be alerted if the limit is frequently exceeded. The final adjustment of both

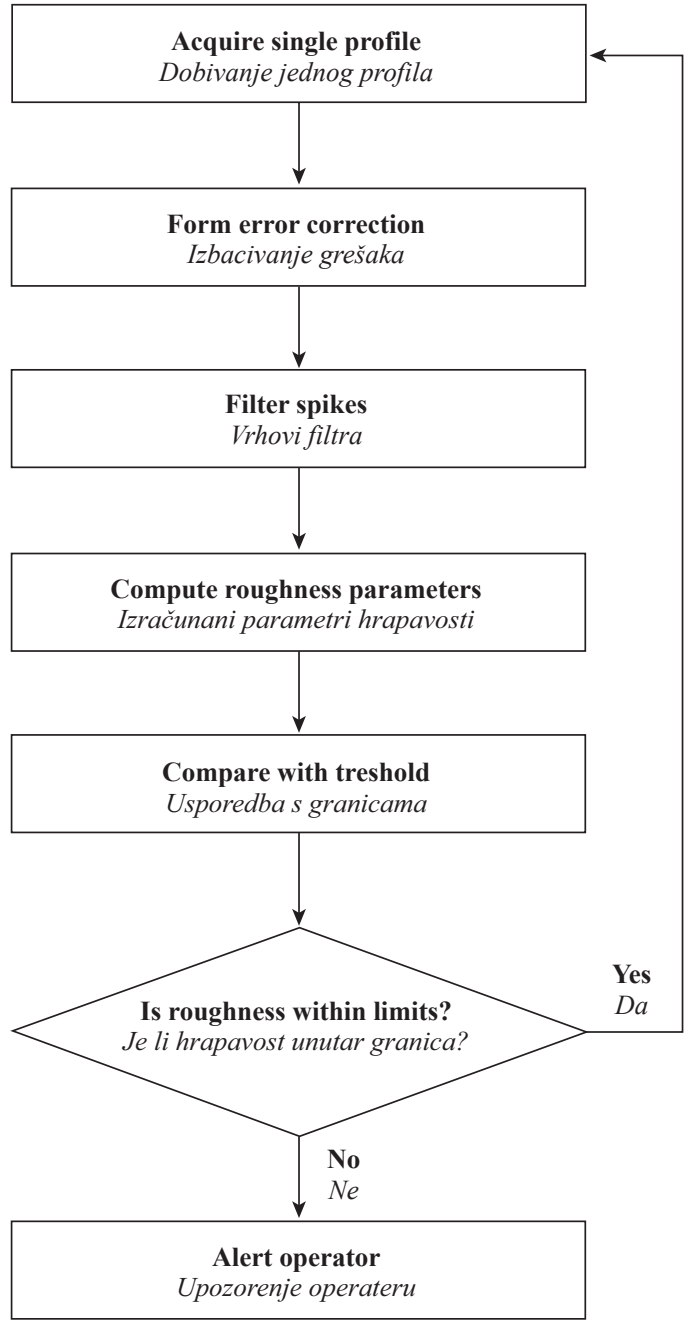

Figure 3 Algorithm for implementing a simple monitoring system alerting machine operation about excessive surface irregularities resulting from the machining process

Slika 3. Algoritam za primjenu jednostavnog sustava praćenja koji upozorava na rad stroja i nastajanje prevelikih neravnina tijekom procesa obrade

threshold and allowed limit exceeding was not performed within the framework of this research. It has to be confronted with real production requirements in the case of future implementation of the system. Nevertheless, the value of the threshold should reflect the specific quality requirements for each component type and be closely related to the statistical process control data provided by the production managers.

\section{RESULTS AND DISCUSSION} 3. REZULTATI I RASPRAVA

Figure 4 presents a direct comparison of profiles extracted for the 3D surface smoothness maps for both sensors tested on-line. It is evident that both provided very similar profile outlines, with LJ-7020 being slightly more precise in representation of the short wavelength components. Both the spatial distribution of irregularities and these heights are matching. It indicates high suitability of both sensors for practical implementation.

The scanning frequency affects the number of details (profiles) used for the detection of surface defects. 


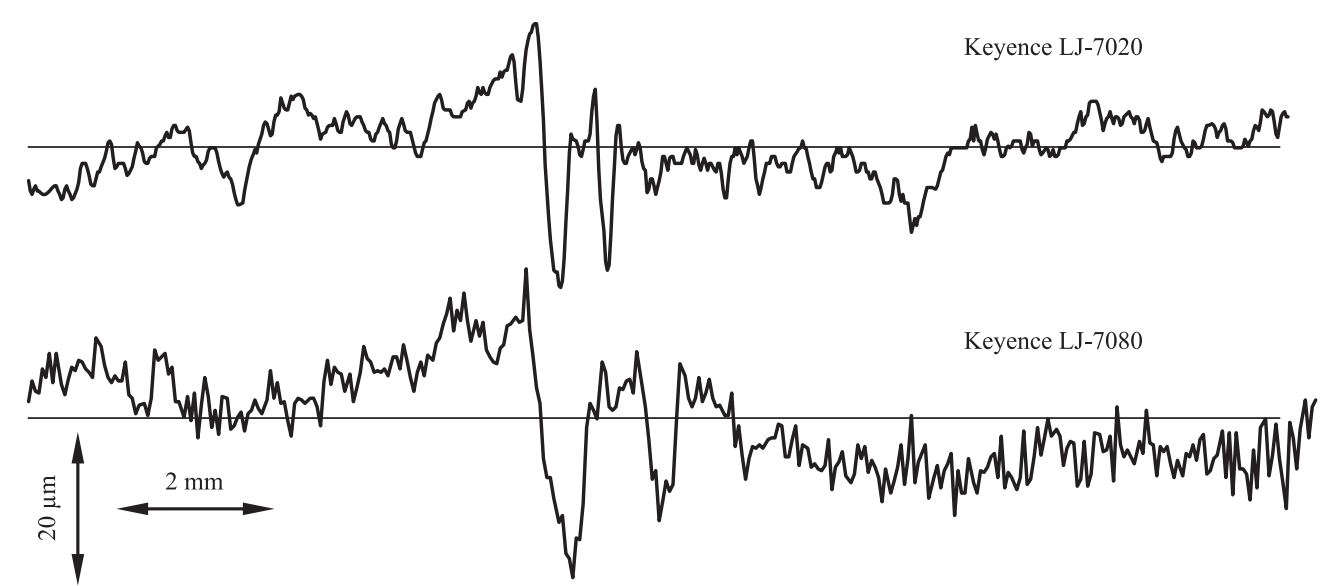

Figure 4 Comparison of profiles extracted from 3D map of sanded and painted window frame surface made of Scots pine measured with Keyence LJ-7080 (top) and LJ-7020 (bottom)

Slika 4. Usporedba profila ekstrahiranih iz 3D karte brušene i premazane površine prozorske okvirnice od borovine i izmjerene uz pomoć senzora Keyence LJ-7080 (gore) i LJ-7020 (dolje)

Figure 5 presents the results of scanning of the same specimen with the frequency of 200, 1000 and $2000 \mathrm{~Hz}$. The arrow corresponds to the same reference length. The spatial resolution is, therefore, 10 times higher in the case of $2000 \mathrm{~Hz}$ scanning, providing also 10 times more data to be processed in real time. As the presence of torn grain was hardly detected on the $200 \mathrm{~Hz}$ scanning frequency, it was assumed that $1000 \mathrm{~Hz}$ was an optimal scanning frequency with conveyor feed speed of $5 \mathrm{~m} / \mathrm{min}$.

According to production managers, torn grain was considered the most problematic surface defect (Farrokhpayam et al., 2010). The specific characteristics of torn grain (void under the mean surface line of relatively high depth and width) allow automatic detection by simple thresholding of the surface image after removing the form error. Figure 6 presents an example of torn grain as sensed on-line with the triangulation sensor. It is also evident that the appearance of the surface profile corresponding to earlywood and latewood differs. It is not clear, however, if the differences are affected by the anatomical structure topography or by differences in laser light scattered on optically varying wood zones. Additional laboratory tests with benchmark references method are therefore required to ultimately define the triangulation sensor limitations.

Other surfaces were also tested in the pilot installation, with some of the results summarized in Figure 7. The $3 \mathrm{D}$ surface map, generated on the basis of sen- sor readings as well as $P \mathrm{q}$ smoothness computed for each profile along the scanning length, are presented for samples provided by production managers. As mentioned above, it was rather easy to detect torn grain as these irregularities have high $\mathrm{Pq}$ values. The results follow the expected trends, where the implementation of technological operations (with the exception of wetting) reduced overall smoothness. The surface roughness of finished surfaces was the smallest and most uniformly distributed along the sample length.

Figure 8 presents an example of representative profiles scanned on model samples, including sections covering defects or other distinctive topography features. The presence of torn grain is evident in samples \#2, \#4 and \#6. Moreover, the decrease of smoothness profile amplitude is noticeable during the implementation of subsequent finishing process steps. The smoothest surfaces are perceived for coated samples, with the exception of \#6 where wavy structure is related to the presence of miniature torn grains and surface pattern on early- and late- wood caused by water-based coating.

A comparative summary of these measurements is presented in Figure 9 as a histogram of $P q$ smoothness determined for each sample. The roughest were rough planed board (\#1) and excessive torn grain (\#2), in contrast to the coated white sample (\#8) with a single histogram peak in the lowest smoothness bin. The histogram analysis was found as the most promising
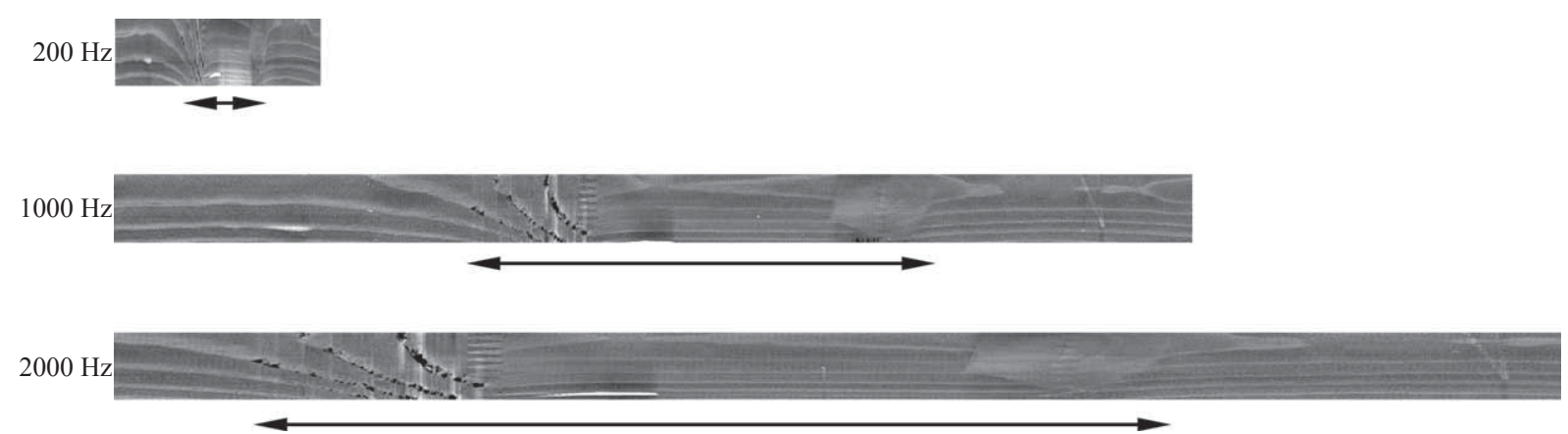

Figure 5 3D surface irregularity map of wooden board including torn grain and filler scanned with different sampling frequencies and constant feed speed $(5 \mathrm{~m} / \mathrm{min})$

Slika 5. 3D karta nepravilnosti površine drvene ploče koja obuhvaća iskidanu žicu i kit, skenirana različitom frekvencijom uzorkovanja i uz konstantnu brzinu ulaganja $(5 \mathrm{~m} / \mathrm{min})$ 


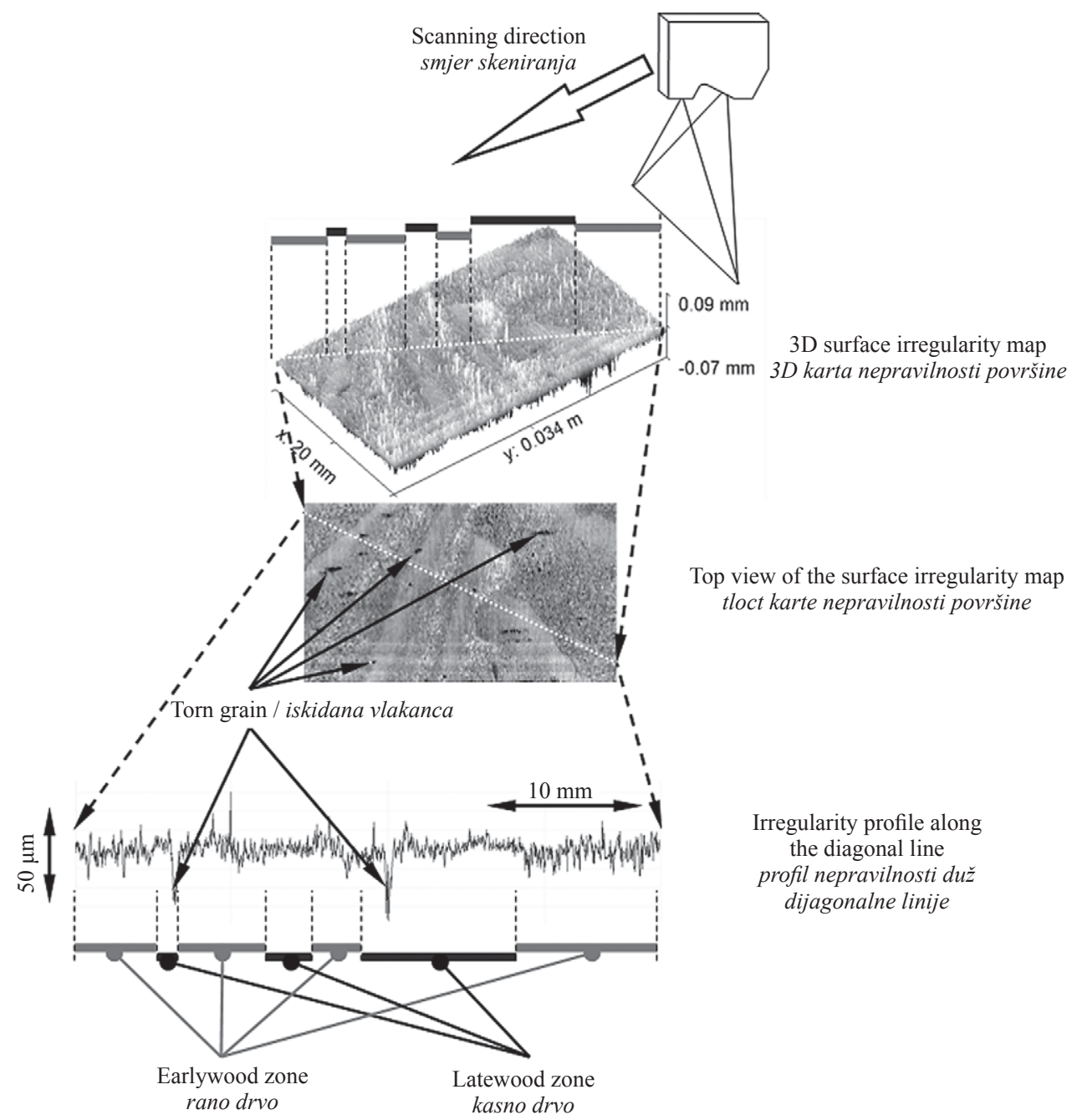

Figure 6 Torn grain, early- and late-wood identified on 3D surface irregularity map of sanded Scots pine surface and on extracted irregularity profile (sensor LJ-7080)

Slika 6. Iskidana žica te rano i kasno drvo otkriveni na 3D karti nepravilnosti brušene površine borovine i na ekstrahiranom profilu nepravilnosti (senzor LJ-7080)

tool for real-time implementation of the on-line surface smoothness measuring system. Again, final adjustments (setting the bin size, threshold level and its value) have to be defined case-by-case during routine operation of the scanner.

\section{CONCLUSIONS \\ 4. ZAKLJUČAK}

The present research was triggered by discussion with production managers raising an emerging problem of wood surface smoothness assessment in industrial realities. Optimal sensors for refined (Keyence LJ-7020) and accurate enough (Keyence LJ-7080) scanning of the wood surface topography were tested in an industrial environment in-line and on-line. Both sensors proved their usability and were able to access surfaces of diverse qualities and finishing states. A simple algorithm for real-time data processing has been proposed and implemented as a prototype. The followup to this project, including the development of a dedicated portable scanner for in-field inspection of produced elements with an optional integration to the processing lines, is currently under way.

\section{Acknowledgements - Zahvala}

The authors gratefully acknowledge the European Commission for funding the InnoRenew project (grant agreement \#739574) under the Horizon2020 Widespread-Teaming program and the Republic of Slovenia (investment funding of the Republic of Slovenia and the European Union's European Regional Development Fund) and infrastructural ARRS program IO-0035.

"Delivering fingertip knowledge to enable service life performance specification of wood" - CLICK DESIGN ( ${ }^{\circ}$ 773324) supported under the umbrella of ERA-NET Cofund ForestValue by Ministry of Education, Science and Sport of the Republic of Slovenia. ForestValue has received funding from the European Union's Horizon 2020 research and innovation programme.

The anonymous window producer company and its production managers are acknowledged for allowing pilot tests on their production lines. Thanks to Keyence Europe, and especially Tomasz Michalski, for renting sensors and technical assistance during the pilot tests.

Part of this research has been presented during 24th International Wood Machining Seminar held at Oregon State University, Corvallis (USA) on August $25-30,2019$. 
..... Sandak, Orlowski, Sandak, Chuchala, Taube: On-Line Measurement of Wood Surface...

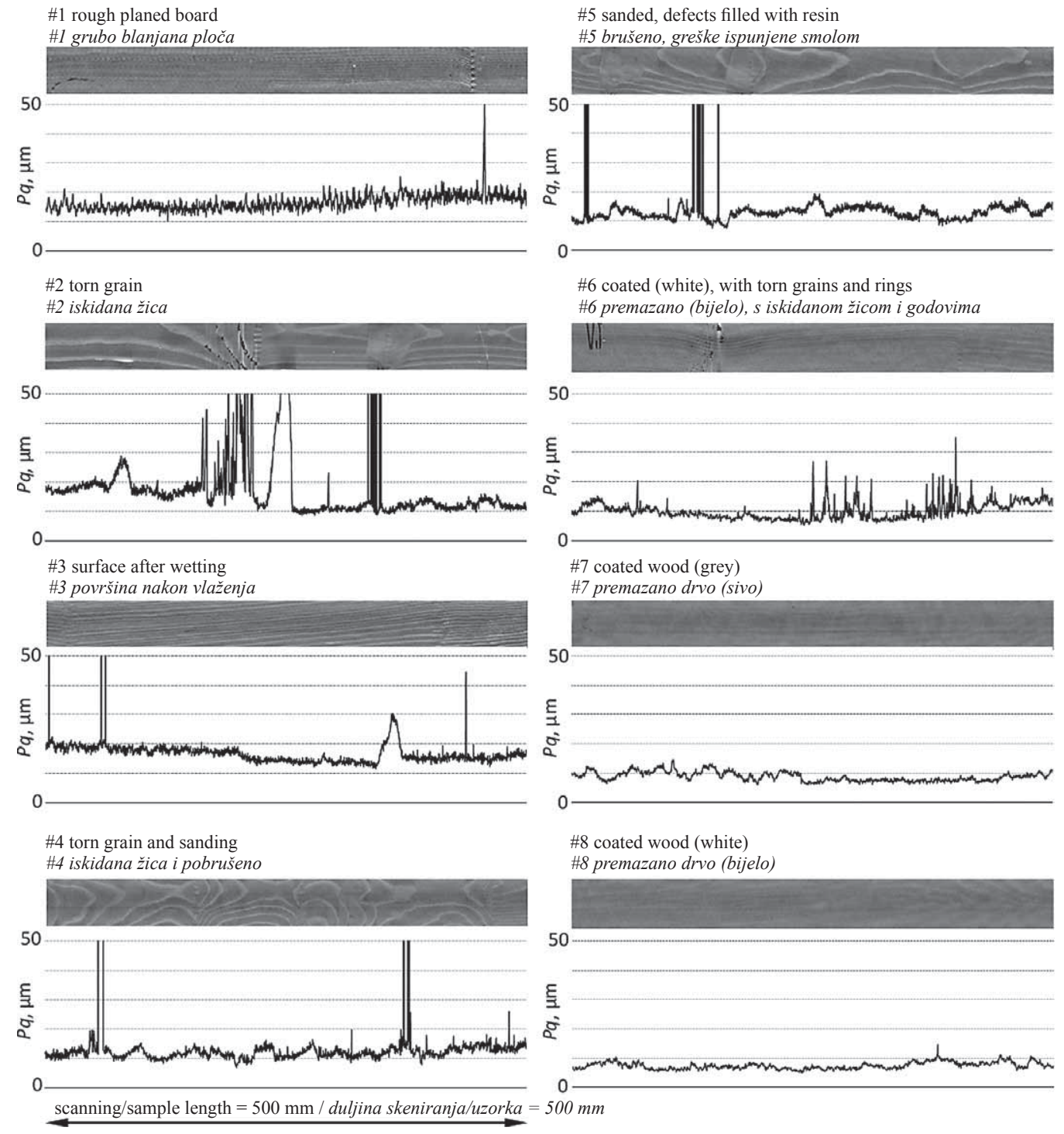

Figure 7 3D surface irregularity maps (grey scale) and $P$ q smoothness variation along wooden boards representing diverse stages of window frame finishing as scanned with Keyence LJ-7080 sensor

Slika 7. 3D karta nepravilnosti površine (siva skala) i $P$ q varijacija glatkoće uzduž drvenih ploča koje predočuju različite faze površinske obrade prozorske okvirnice kao što je skenirano senzorom LJ-7080

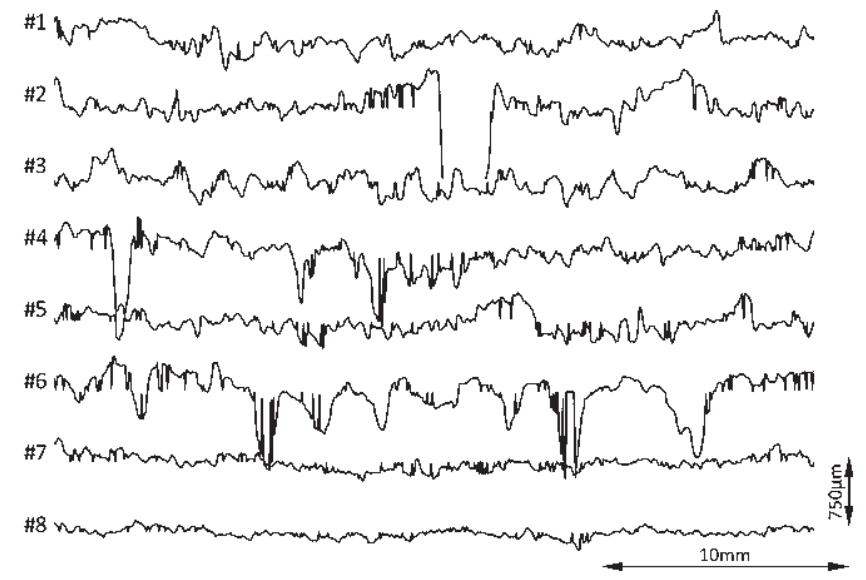

Figure 8 Profiles extracted from 3D surface irregularity maps of Scots pine boards representing diverse stages of window frame finishing as scanned with Keyence LJ-7080 sensor: \#1 - rough planed board, \#2 - torn grain, \#3 - surface after wetting, $\# 4$ - torn grain and sanding, $\# 5$ - sanded, defects filled with resin, \#6 - coated (white), with torn grain and yearly rings, \#7 coated wood (grey), \#8 - coated wood (white)

Slika 8. Profili ekstrahirani iz 3D karti nepravilnosti površine ploča od borovine koji predočuju različite faze površinske obrade prozorske okvirnice skenirane senzorom Keyence LJ -7080: \#1 - grubo blanjana ploča, \#2 - iskidana vlakanca, \#3 - površina nakon vlaženja, \#4 - iskidana žica i pobrušeno, \#5 - brušeno, greške ispunjene smolom, \#6 - premazano (bijelo), s iskidanom žicom i godovima, \#7 - premazano drvo (sivo), \#8 - premazano drvo (bijelo) 


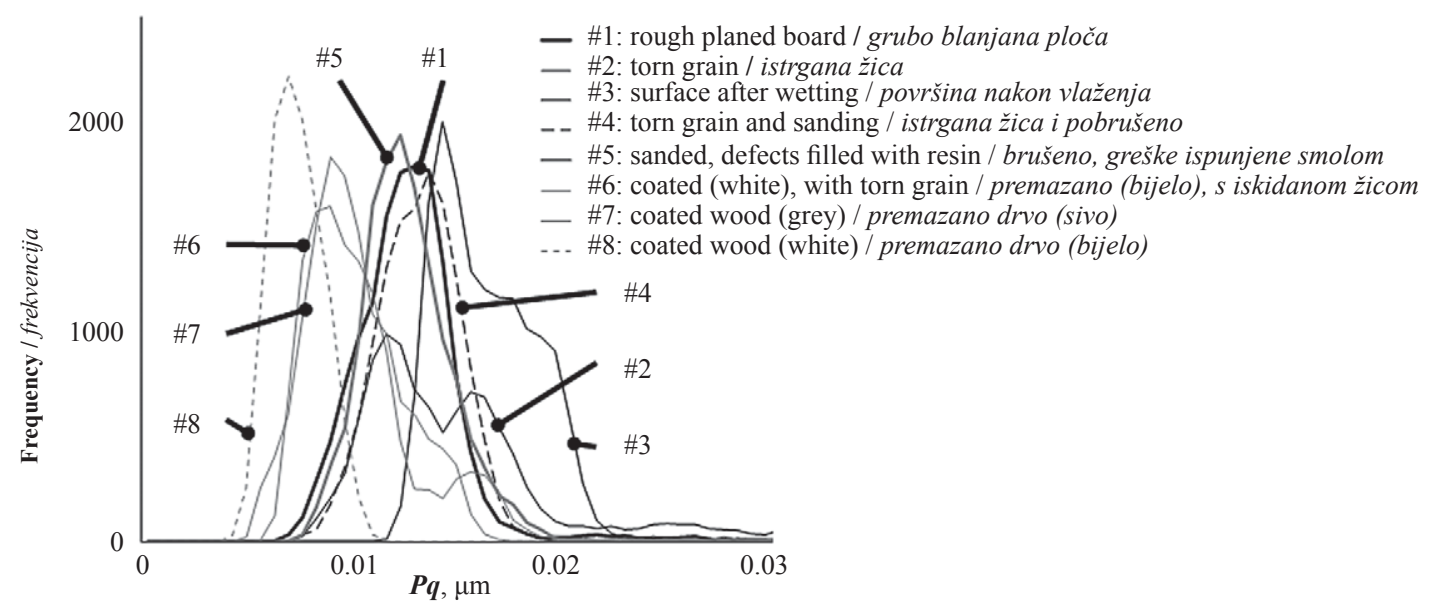

Figure 9 Histogram of $P$ q smoothness parameters measured on-line with Keyence sensor LJ-7080 on different wood surfaces (feed speed $2 \mathrm{~m} / \mathrm{min}$ )

Slika 9. Histogram $P$ q parametara glatkoće izmjerenih online senzorom Keyence LJ-7080 na različitim površinama drva (brzina ulaganja $2 \mathrm{~m} / \mathrm{mm}$ )

\section{REFERENCES}

\section{LITERATURA}

1. De Groot, P. J., 2019: A review of selected topics in interferometric optical metrology. Reports on Progress in Physics, 82: 056101.

https://doi.org/10.1088/1361-6633/ab092d.

2. Dobrzynski, M.; Orlowski, K. A.; Biskup, M., 2019: Comparison of surface quality and tool-life of glulam window elements after planing. Drvna industrija, 70 (1): 7-18. https://doi.org/10.5552/drvind.2019.1741.

3. Farrokhpayam, S. R.; Ratnasingam, J.; Bakar, E. S.; Tang, S. H., 2010: Characterizing surface defects of solid wood of Dark Red Meranti (Shorea sp.), Melunak ( Pentace sp.) and Rubberwood (Hevea brasiliensis ) in planing process. Journal of Applied Sciences, 10 (11): 915 918. https://doi.org/10.3923/jas.2010.915.918.

4. Kiliç, M.; Pürlusoy, I.; Kurnali, M., 2018: Measuring the surface roughness values of european hop-horn beam. Wood Research, 63 (2): 343-352.

5. Lu, R. S.; Tian, G. Y., 2006: On-line measurement of surface roughness by laser light scattering. Measurement Science and Technology, 17 (6): 1496-1502. https://doi.org/10.1088/0957-0233/17/6/030.

6. Lu, L.; Ding, Y.; Luan, Y.; Yin, Y.; Liu Q.; Xi, J., 2017 : Automated approach for the surface profile measurement of moving objects based on PSP. Optics Express, 25 (25): 32120-32131. https://doi.org/10.1364/oe.25.032120.

7. Lu, Z.; Wang, M.; Dai, W., 2019: Machined surface quality monitoring using a wireless sensory tool holder in the machining process. Sensors, 19 (8): 1847.

https://doi.org/10.3390/s19081847.

8. Manuel, A.; Leonhart, R.; Broman, O.; Becker, G., 2015: Consumers' perceptions and preference profiles for wood surfaces tested with pairwise comparison in Germany. Annals of Forest Science, 72 (6): 741-751. https://doi.org/10.1007/s13595-014-0452-7.

9. Molnár, Z.; Fuchs, I.; Tatai, S.; Magoss, E., 2019: Stability of planed and precision planed solid wood surface due to wetting. Maderas. Ciencia y tecnología, 21 (1): 123132.https://doi.org/10.4067/s0718-221x2019005000112.

10. Nasir, V.; Cool, J., 2018: A review on wood machining: characterization, optimization, and monitoring of the sawing process. Wood Materials Science \& Engineering, 15 (1): 1-16. https://doi.org/10.1080/17480272.2018.1465465.
11. Sandak, J., 2007: Optical triangulation in wood surface roughness measurement. In: Proceedings of the $18^{\text {th }} \mathrm{In}-$ ternational Wood Machining Seminar. Vancouver, Canada, vol. 1, pp. 275-284.

12. Sandak, J.; Negri, M., 2005: Wood surface roughness What is it? In: Proceedings of the $17^{\text {th }}$ International Wood Machining Seminar. Rosenheim, Germany, vol. 1, pp. 242-250.

13. Škaljić, N.; Beljo Lučić, R.; Čavlović, A.; Obućina, M., 2009: Effect of feed speed and wood species on roughness of machined surface. Drvna industrija, 60 (4): 229-234.

14. Sofuoğlu, S. D.; Kurtoğlu, A., 2015: Effects of machining conditions on surface roughness in planing and sanding of solid wood. Drvna industrija, 66 (4): 265-272. https://doi.org/10.5552/drind.2015.1406.

15. Šustek, J.; Siklienka, M., 2018 The effect of laser beam wavelengths on accuracy of surface measurement of unevenness of beechwood by laser beam. Acta Facultatis Xylologiae Zvolen, 60 (1): 137-145.

16. Zhao, X., 1992: Study on measurement of wood surface roughness by computer vision. Journal of Northeast Forestry University, 3 (1): 75-81.

17. Zhao, X., 1995: Inspecting wood surface roughness using computer vision. In: Proceeding of SPIE 2345 Optics in Agriculture, Forestry, and Biological Processing. Boston, United States. https://doi.org/10.1117/12.198860.

18. Župerl, U.; Čuš, F., 2019: A cyber-physical system for surface roughness monitoring in end-milling. Strojniški vestnik - Journal of Mechanical Engineering, 65 (2): $67-$ 77. https://doi.org/10.5545/sv-jme.2018.5792.

19. ***Keyence, 2019: https://www.keyence.com/products/ measure/laser-2d/lj-v/index.jsp (Accessed Nov 3, 2019).

20. $* * *$ Gwyddion, 2019:

http://gwyddion.net/ (Accessed Nov 3, 2019).

\section{Corresponding address:}

\section{JAKUB SANDAK, PhD}

InnoRenew CoE

Livade 6

6310 Izola, SLOVENIA

e-mail: jakub.sandak@innorenew.eu 